\title{
Tropical ash (Fraxinus udhei) invading Andean forest remnants in Northern South America
}

\author{
Kelly A. Saavedra-Ramírez*, Andrés Etter and Alberto Ramírez
}

\begin{abstract}
Introduction: Exotic invasive species represent a major driver of the loss of biological diversity and services provided by ecosystems globally. An important cause of species becoming invasive is the development of commercial afforestation projects using fast-growing and adaptable exotic species, which may become invasive impacting natural environments. The tropical ash (Fraxinus uhdei), native to México, has been widely introduced to Colombia and other countries for timber, live fences, and urban greening. It is now common in many areas of the tropical mountains and has been observed expanding into native forests in Colombia.

This study examined the invasion pattern and the demographic structure of tropical ash in remnant Andean forests in Colombia, to find out factors associated with the invasion process. The analysis took into account biotic and physical factors: distance to propagule source, vegetation cover types, and understory and canopy cover.

Results: Although the reproductive strategy of the tropical ash is of " $r$ " type with low survival rates, the results show evidence for an active process of invasion characterized by an aggregated distribution pattern dominated by seedlings and juvenile plants. The study shows the existence of an interaction between the distance to propagule source and the vegetation cover, which has an additive effect on the demographic structure of the population.

Conclusions: This study suggests an active invasion process by the exotic tree tropical ash into a remnant of sub-humid forests in the Andean highlands. Our results showed an expanding population process with a decreasing average age from propagule sources and mature reproductive individuals within the native forest, which bring new individuals that are colonizing new areas and advancing into the forest. This research points to the need for urgent plant intervention on two aspects: the use of the tropical ash and the management of the invasion process in native forests.
\end{abstract}

Keywords: Andean forest, Demographic structure, Fraxinus uhdei, Exotic species, Plant biological invasions, Invasion pattern

\section{Introduction}

The processes of land clearing, habitat modification and the invasion of exotic species, together with pollution and climate change, represent the major drivers of the loss of biodiversity and services provided by native ecosystems (Millenium Ecosystem Assessment-MEA 2005). As a response to soil and water degradation and wood and timber shortages from the extensive clearing of forests worldwide (Food and Agriculture Organization of the United States-FAO 2014), commercial reforestation

\footnotetext{
* Correspondence: kelly.saavedra@hotmail.com

Departamento de Ecología y Territorio, Pontificia Universidad Javeriana, Bogotá, Colombia
}

and afforestation projects that use fast-growing timber species have been carried out extensively (Trujillo 2012). Indeed, a significant proportion of invasive species in tropical forest are woody, and the pathway of introduction is forestry, because most of the time, foresters bring aggressive species such as woody legumes, which dominate much non-industrial tree planting (Hughes 1994).

Mountain forests are valued worldwide for their fundamental role in the processes of biodiversity conservation, hydrologic regulation, carbon storage, and net primary productivity (Galbraith et al. 2014). The Andes Mountains of northern South America, and especially Colombia, are known for their high biodiversity and high levels of endemism (Hernández-Camacho et al. 1992) 
and constitute a global hotspot of biodiversity (Myers et al. 2000; Orme et al. 2005). However, the Colombian Andes have been subject to large-scale deforestation (Etter et al. 2008), and as a consequence of this, reforestation projects to protect watersheds, water sources, and degraded soils have been underway for several decades, often extensively planting exotic species such as Acacias (Acacia sp.), Pines (Pinus sp.), Eucalypts (Eucalyptus sp.), and Ash (Fraxinus sp.) (Berrio et al. 2006). Regarding the effects of invasive exotic species on Andean forests, there have been studies that support impacts such as loss of native biodiversity (Gutiérrez 2006), the alteration of the dynamics of pollination and colonization of native species (Martyniuk et al. 2015; Aizen et al. 2008), the reduction of structural diversity (Gareca et al. 2007), the disruption of prevailing vegetation and soil dynamics (Gareca et al. 2007; Richardson and Cowling 1994), and habitat alteration (Morales and Aizen 2002; Crichigno et al. 2016).

Biological invasions depend on the ability of the invasive species to establish and spread (invasiveness), and the susceptibility of the ecosystem to the invasion (invasibility) (Colautti et al. 2006; Lamarque et al. 2011). An important invasiveness factor is the availability of propagules, which control the probabilities of establishment, persistence, naturalization, and invasion (Rouget and Richardson 2003; Catford et al. 2011). In the case of invasibility, the two important factors that make a habitat susceptible to invasion are (a) resource fluctuations (Booth et al. 2004; Inderjit 2005), including soil pH, soil humidity, plant litter (Alston and Richardson 2006), and availability of nutrients such as phosphorus and calcium (Alpert et al. 2000), and (b) disturbance (Fine 2002; Inderjit 2005), including degree of erosion or changes in canopy and understory cover (Alston and Richardson 2006).

Tropical ash propagation is stimulated by high soil moisture availability, fertility, and soil depth conditions (National Commission for Knowledge and Use of Biodiversity - CONABIO 2008), though other authors suggest that tropical ash invasions are more intense on fertile soils and along streams (Harrington and Ewell 1997; Villanueva et al. 2015). However, there is good evidence that supports that tropical ash colonizes more easily forest edges and disturbed areas (Weber 2003) because wind and precipitation are suitable mechanisms for the dispersion of its seeds, which have dormant capacity for 6 years or more (US Forest Service, Pacific Island Ecosystem at Risk-PIER 2008).

In Colombia, tropical ash (locally known as "Urapán") presents a moderate to high invasion risk; however, more in-depth analyses are needed because current information of biology, ecology, impacts, and management is insufficient (Baptiste et al. 2010).

The objective of the study was to investigate the invasion pattern of tropical ash in human-transformed landscapes. To this end, we addressed three aspects: (i) the demographic structure of the species, (ii) its spatial distribution pattern in the landscape, and (iii) the effects of biophysical variables (distance to propagule source, vegetation cover type, understory cover and canopy cover) on its spatial distribution.

A previous study by Arévalo (2009) found some evidence that the growth and establishment patterns of tropical ash depend on the type of vegetation and on the distance to the seed source. According to the biological invasion framework previously presented, we expected the invasion pattern to be determined by the effect of the biophysical variables on the demographic structure and the spatial distribution pattern. We expected an inverse relation between distance to propagule source and the abundance of individuals, a spatial distribution more linked to the establishment ability of the species in a disturbed area than to its soil preferences, and significant differences in densities and age structure in each vegetation cover type and distance class to the seed source.

\section{Methods \\ Study area}

The study site is located in the Bogota Highplain in the central part of the Eastern Andes of Colombia, northwest of the capital Bogotá. It covers an approximate area of 200 hectares, on the western side of the Majuy mountain range in the Municipality of Tenjo (Cundinamarca Department) (Fig. 1). The Majuy mountain range is an area of interest for conservation and considered as a key to the ecological infrastructure of the Bogotá Highplain region because it contains one of the better-conserved and largest native forest remnants of the region (Montañez and Cereh 2013). In addition, there is evidence of tropical ash invading the area (Arévalo 2009) which makes it an ideal study site.

The Bogotá Highplain is part of the wider region known as the Cundinamarca-Boyacá high-plains of the Eastern Cordillera, which covers an area of 200,000 hectares (EcoNat Ltda and Fundación Cerros de Bogotá 2013). There is an old fluvio-lacustrine plain with average altitude of $2600 \mathrm{~m}$, crisscrossed by several northsouth cretaceous and tertiary sandstone mountain ranges up to $3500 \mathrm{~m}$ high, of which Serranía Majuy is one (EcoNat Ltda and Fundación Cerros de Bogotá 2013). The Majuy range covers some 3000 hectares and reaches an altitude of $3000 \mathrm{~m}$ asl.

Serranía Majuy presents slopes that vary from 25 to more than $50 \%$, with mostly superficial and relatively young entisols soils, with some inclusions of andisols where volcanic ashes accumulated. These soils are generally of low fertility, with a $\mathrm{pH}$ varying from acid (5.5) to very acid (4.5), and have a low base and phosphorus contents (Rodríguez 1997). 


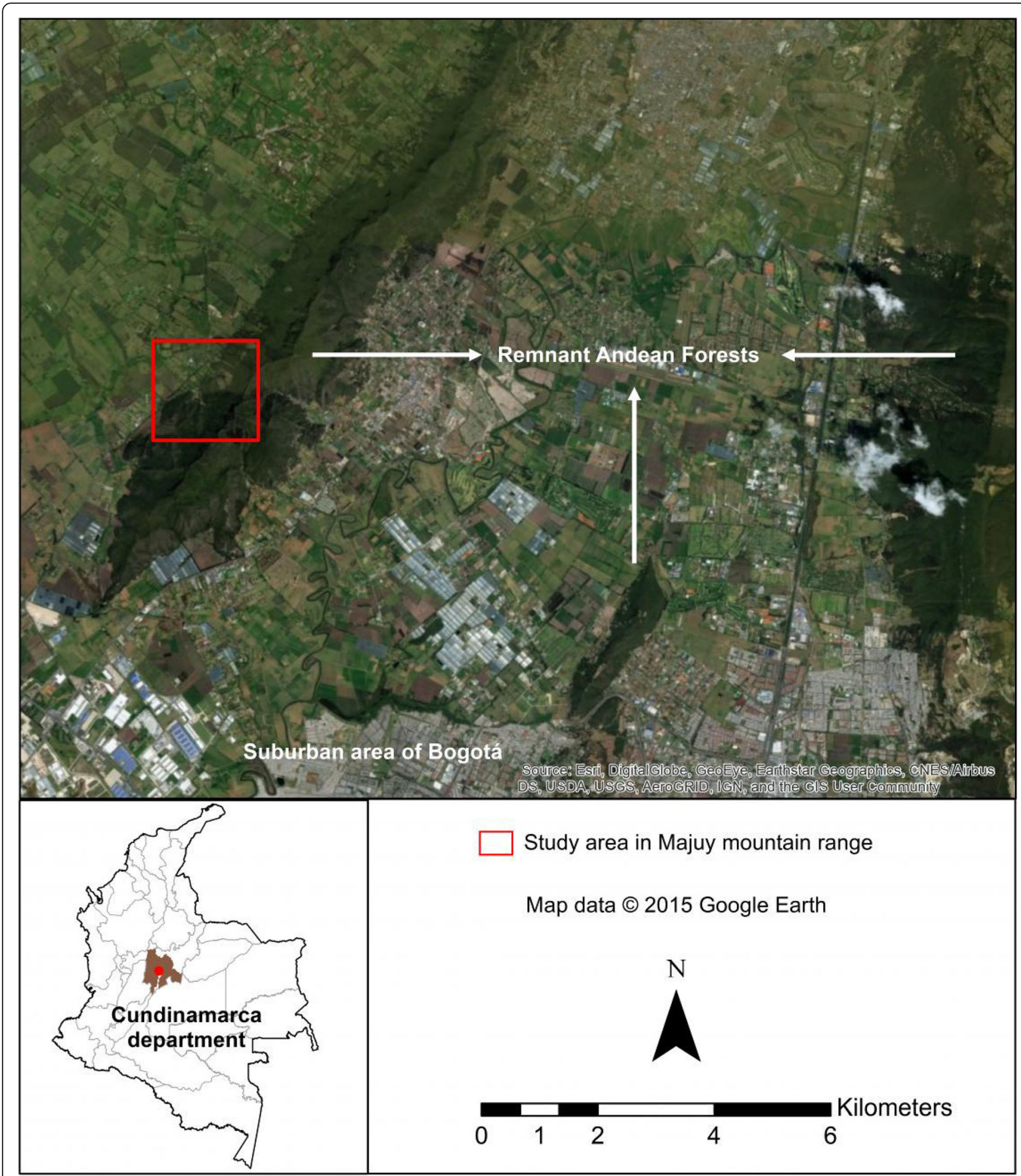

Fig. 1 Study area to the northwest of Bogotá in Tenjo, Cundinamarca. Study area (red rectangle) covering part of the hills and low mountains within the Bogotá High plain. Dark green areas correspond to native vegetation remnants, mostly forests; light green and orange to pastures and crops; and beige to urban centers (Map data @ 2015 Google Earth)

The climate is sub-humid and cool, with an annual rainfall of around $900 \mathrm{~mm}$, distributed in two rainy seasons (April-June and September-November), with two to four dry months. Average temperature is $16{ }^{\circ} \mathrm{C}\left(0-22{ }^{\circ} \mathrm{C}\right)$, and wind direction is predominantly from the northwest (Colombian Institute of Hydrology Meteorology and Environmental Studies-IDEAM 2014). The remnant Andean Forest of Serranía Majuy is mostly privately 
owned but must comply with use restrictions because it is an area within the Protective Forest Reserve of the Upper Bogotá River Basin (Montañez and Cereh 2013). The surrounding plains consist of a mosaic of pastures, crops, greenhouses used for floriculture, and suburban areas, bordered by live fences of native and introduced species. Common introduced trees in live fences include the tropical ash and Acacias (Acacia decurrens and Acacia mangium).

\section{Study species}

Tropical ash (Fraxinus uhdei (Wenz) Lingelsh) is one of the species introduced in the Andean region of Colombia more than 60 years ago, for urban greening (Infante 1958) and for reforestation (García and Murcia 2005). Tropical ash has a natural distribution in the highlands of west and southern Mexico, and south Guatemala and Honduras, at altitudes between 1100 and $2600 \mathrm{~m}$ (US Forest Service, Pacific Island Ecosystem at Risk-PIER 2008). Tropical ash lives as long as 80100 years (CONABIO 2008); it produces annually large quantities of wind-dispersed seeds and has rapid growth with a high regeneration capacity (Tunison 1995). Tropical ash was included in the group of the greatest invasive species of islands worldwide (Smith 1985), forming dense stands from which most native species are excluded. Additionally, Rothstein et al. (2004) point that this species affects phosphorus and carbon cycles and forest decomposition dynamics in islands.

\section{Land cover map}

We constructed a land cover map using a highresolution satellite image $(0.5 \mathrm{~m})$ from the year 2009 from the Worldview 2 satellite (DigitalGlobe 2009). We applied a segmentation procedure with the mean-shift nonparametric iterative algorithm, using the Monteverdi software (Grizonnet and Inglada 2010), which consists of a process of grouping pixels with regard to one or more cover characteristics (OTB Team 2014). Based on the best results of the segmentation, assessed by the number of generated regions and the concordance with a preview visual interpretation of the image, we constructed the land cover map using ArcGIS 10 software (ESRI 2010).

Five land cover types were identified and delineated: (a) tall native forest, an Andean native vegetation cover represented by large, tall mature trees $(15-20 \mathrm{~m})$, located among the mountains' slopes, with four easily identified strata: dense canopy of large crowns, lower tree stratum $(7-10 \mathrm{~m})$, shrub stratum, and herbaceous layer; (b) low native forest, an Andean native vegetation cover represented by medium-size trees (10-15 m), located in the mountains' slopes and foots, with three easily identified strata: dense to open canopy, lower tree stratum $(5-7 \mathrm{~m})$, and herbaceous layer; (c) native shrubland, an Andean native vegetation cover represented by small trees and bushes $(2-3 \mathrm{~m})$, located mostly in the mountains' summits and areas with high slopes; (d) hedgerows, lines of closely spaced native or introduced trees species, planted to mark the farms boundaries; (e) woody pasture, a cover with sparse woody vegetation across pastures, (f) pastures and crops, open pasture surfaces containing no woody vegetation and floriculture areas; (g) infrastructure; and (h) forest plantation, a non-native cover dominated by Eucalyptus sp.

\section{Biophysical variables}

To determine factors associated with the invasion of tropical ash, we measured four biophysical variables. The natural woody vegetation covers were determined as the native cover types within the Andean forest remnant (tall forest, low forest, and shrubland). The distance classes from propagule source were calculated as the Euclidean map distance from the present points of the introduced tropical ash trees (seed source trees located in fence lines and taken from Arévalo (2009). As a result, a distance map with two classes was created in order to assure each cover type was represented in an area portion in each distance class and to avoid particular distance classes being biased towards certain cover types, $0-300 \mathrm{~m}$ and 300-600 m (Fig. 2).

The understory cover was measured as an ordinal variable ( 1 to 5 , sparse to dense), assigned based on a visual estimate of percentage cover of understory plants over a circular plot of $2 \mathrm{~m}$ diameter around each tropical ash individual. Finally, the canopy cover, as a quantitative variable (\%), was measured with one densitometer reading over the 2-m circular plot of each tropical ash individual. These data were grouped into five categories, $1=<20 \%$ of the plot, $2=20-40 \%, 3=40-60 \%, 4=60-80 \%$, and $5=>80 \%$.

\section{Fieldwork}

The fieldwork was performed between August and September of 2014. With the purpose of defining the tropical ash range in the study area, an individual-based measurement was considered (Yalcin and Leroux 2017). Samples were taken in the form of band transects following a stratification of six cover type-distance classes based on the combination of the three native vegetation cover types and the two distance to propagule source classes: tall forest in 0-300 distance (one sample), tall forest in 300-600 distance (three samples), low forest in 0-300 distance (four samples), low forest in 300-600 distance (two samples), shrubland in 0-300 distance (five samples), and shrubland in 300-600 distance (two samples). 


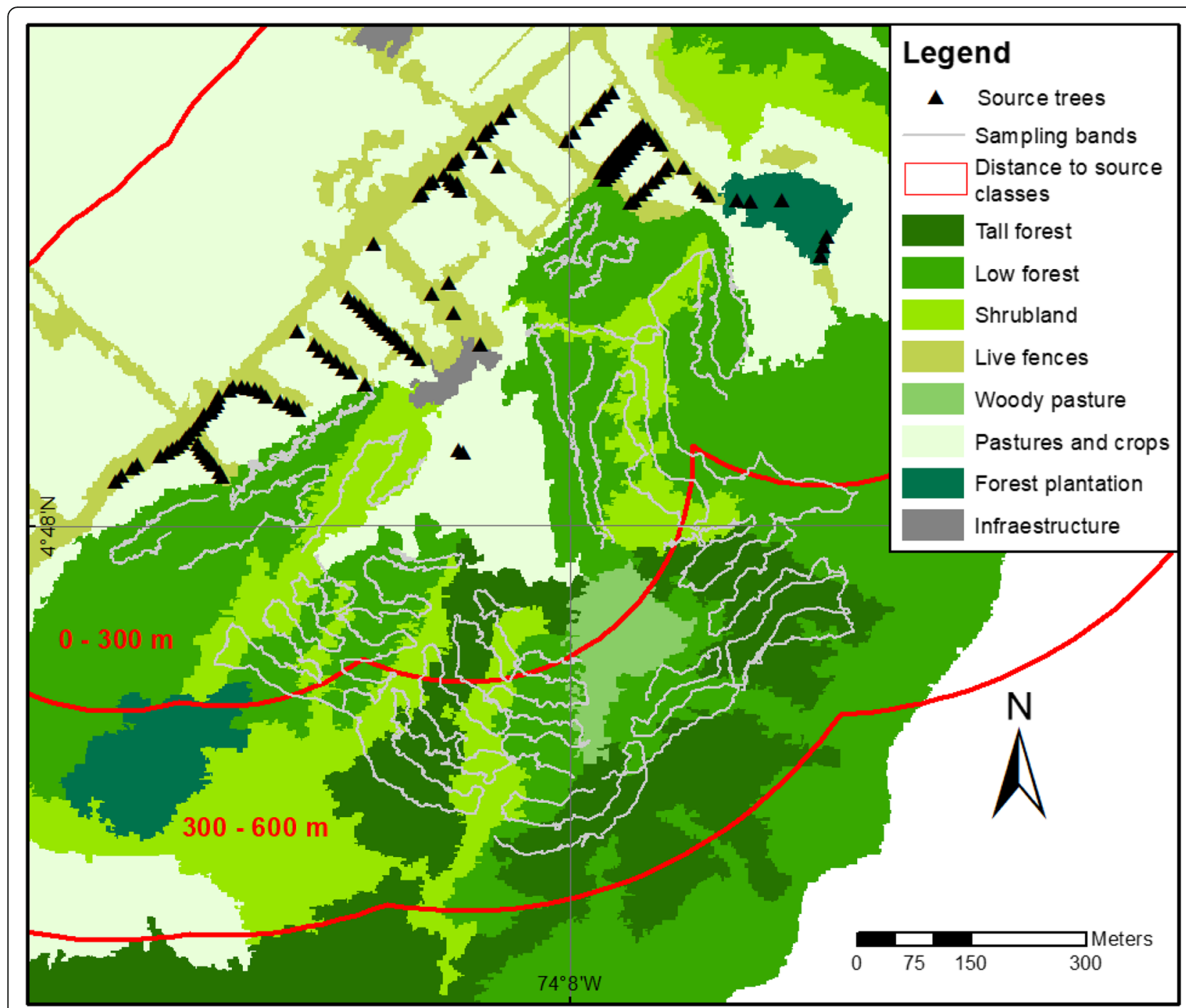

Fig. 2 Land cover map and distance classes. Black triangles represent seed source trees of Fraxinus uhdei. Distance classes were calculated around the seed source trees (red rings)

Within each class cover type-distance, one band transect was traced following a meandering pattern upslope, covering as far as possible the spatial unit being sampled (Yalcin and Leroux 2017) (Fig. 2). The band transects were $3 \mathrm{~m}$ wide, and the length varied according to the area of the cover type-distance class. The first band line in each stratum was about $3 \mathrm{~m}$ of distance from the vegetation cover edge, approximately.

In each transect, all observations of tropical ash were registered (Yalcin and Leroux 2017), and for each individual, the following data were recorded: band transect number, individual number, geographical position system (GPS), woody vegetation cover type, diameter at breast height (DBH), canopy cover (\%), and understory cover class.

\section{Data analysis \\ Density}

The area (hectares) of the traveled transect in each of six cover type-distance classes was calculated by multiplying the length of each transect by its width $(3 \mathrm{~m})$. With these data and the corresponding individual presence, a measure of the density for each cover type-distance class was calculated (individuals/hectare).

\section{Demographic structure}

To explore the demographic structure of the tropical ash population, life stages were defined using plant size categories based on the stem diameter. They were grouped into five categories, $<1 \mathrm{~cm}$ (seedling), $1-2 \mathrm{~cm}$ (juvenile 1), 2-5 cm (juvenile 2), 5-10 cm (juvenile 3), 
and $>10 \mathrm{~cm}$ (adult). The life-stage intervals and limits were determined based on the size classes assigned to Fraxinus species in previous studies (Palik et al. 2012; Kashian 2016; Canham and Murphy 2017). Plotting the abundances of each diameter class yielded an estimation of the survival curve (Lauenroth and Adler 2008). The relation between tropical ash abundance for each diameter class, vegetation cover type, and distance to propagule source was also examined by comparing the age structure for each variable.

\section{Spatial distribution pattern}

In order to analyze the spatial distribution pattern of the tropical ash population, we used Ripley's K function (Haase 1995; Soto et al. 2010), which is a tool for analyzing mapped spatial point process data and is frequently used to analyze spatial patterns of trees (Dixon 2002). It also shows the change in the spatial clustering or dispersion of the centroids of the entity when the size of the neighborhood changes (ArcGIS Resources 2014). The Ripley's K function has been used to describe how point patterns of different plant species or forest landscape types occur over a specific area of interest and how they can change with scale (Dong et al. 2014; Fonton et al. 2011; Muvengwi et al. 2018). Specifically in tropical landscapes, Higuchi et al. (2010) used the function to evaluate the influence of propagule source of an Annonaceae species on an experimental plantation of eucalyptus in Brazil. In Colombia, Vallejo and Galeano (2009) analyzed the changes in the spatial distribution patterns of nine common plant species of an Andean cloud forest by using the Ripley's K function.

\section{Relations with biophysical variables}

For the statistical analysis of biophysical variables, specifically understory and canopy cover, the frequency of the categories of these variables in each cover type were explored. To complement, a frequency comparison test (chi-squared) (Pyle 1995) was done for the following variables: (i) difference in the abundance of diameter categories between cover types and distance classes, (ii) understory cover categories between cover types, and (iii) canopy cover categories between cover types. The statistical analyses were performed using the Past.ver.2.17c software (Hammer et al. 2001).

To address the hypothesis of the impact of the biophysical variables on the population demographic structure and spatial distribution pattern, the Ash individuals were split into three groups of the 5, 10, and 15 largest (mostly adult reproductive) individuals (Mullah et al. 2014). Then, normality and homoscedasticity tests were done for the six cover type-distance. Because of the heterogeneity in variances of the data, we applied a Kruskall-Wallis median comparison test (Dickens and Allen 2013).
The group built with the five largest individuals, as result of the new data treatment described above, was subject to a factorial variance analysis (ANOVA) using the Past.ver.2.17c software (Hammer et al. 2001), to comply with the homoscedasticity condition for a significance level of 3\%, knowing that the typical significance level for this test is $5 \%$. This test was performed to assess whether changes in population demographic structure were consequence of an interaction between the cover type and the distance to the propagule source.

\section{Results}

\section{Land cover classification}

The study area is represented by natural and native covers $(59 \%)$, which include the tall forest $(16 \%, 31 \mathrm{ha})$, the low forest $(32 \%, 60.4 \mathrm{ha})$, and the shrubland (11\%, $20.4 \mathrm{ha}$ ). The remaining $41 \%$ is divided into pastures and crops, hedgerows, woody pastures, forest plantations, and infrastructure (Fig. 2).

\section{Tropical ash abundance and density}

We recorded a total of 2078 tropical ash individuals, 333 (16\%) of which were seedlings $(\mathrm{DBH}<2 \mathrm{~cm})$. Abundance varied a lot, with $6.7 \%$ of individuals (140) found in the tall forest, $74.5 \%$ (1548 individuals) recorded in the low forest, and $18.8 \%$ (390 individuals) in the shrublands.

In relation to the distance to propagule source, $89.6 \%$ (1862 individuals) of the trees were found in the range 0-300 $\mathrm{m}$, and $10.4 \%$ (216 individuals) were recorded in the second range $(300-600 \mathrm{~m})$.

The proportion of individuals recorded in each cover type showed that the low forest presented the greatest number of individuals, whereas the shrubland and the tall forest showed lower densities (Table 1). For the distance classes, densities decreased with distance (Table 1).

Regarding the hypothesis of the inverse relation between the distance to propagule source and the population abundance, an exponential function was set, where a decrease in the number of individuals is related to an increase in the distance to propagule source in live fences (Fig. 3).

\section{Tropical ash demographic structure}

Size class distributions show a decrease in the relative abundances with increasing size (age) of individuals, and

Table 1 Tropical ash density

\begin{tabular}{lll}
\hline Variable & Category & Density (individuals/ha) \\
\hline Vegetation type & Tall forest & 91 \\
& Low forest & 336 \\
& Shrubland & 17 \\
Distance classes (m) & $0-300$ & 362 \\
& $300-600$ & 68
\end{tabular}

Density values into each vegetation type and distance class 


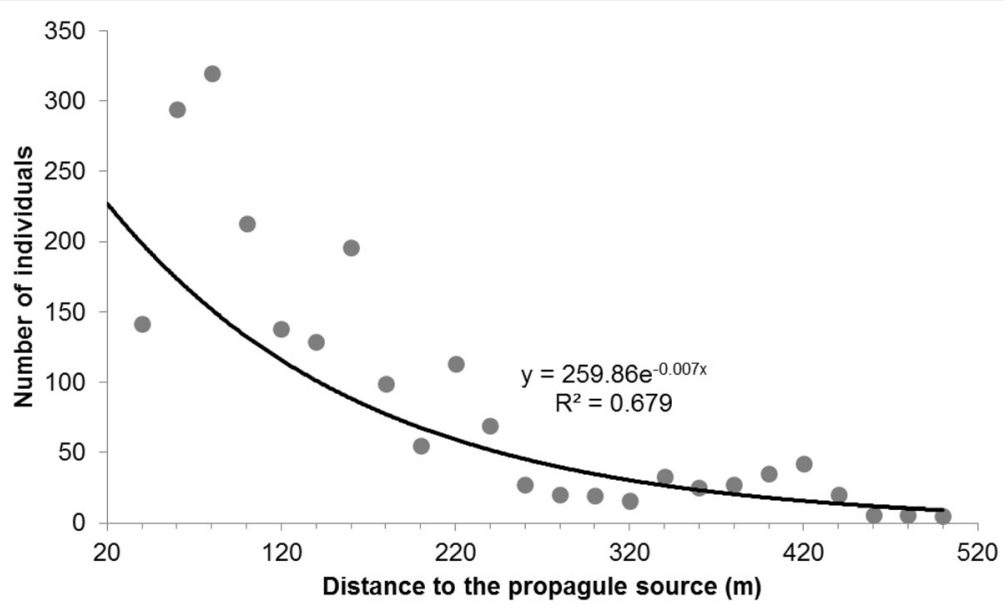

Fig. 3 Distribution of individual abundance in relation to the distance to the propagule sources

consequently, the population consists mainly of seedlings and juvenile plants (Fig. 4). The number of seedlings was correlated with vegetation cover type and distance class, with a reduction in the number of seedlings associated with increasing forest height (Fig. 4a), which was also the case with an increase in distance to the seed source (Fig. 4b).

The overall demographic pattern or "survival curve" of the species showed overall an inverted "J" structure characteristic for an inverse exponential mortality rate (Fig. 5a). The same pattern occurred for low forest and shrubland; however, in the case of the tall forest, the best data adjustment was a polynomial function (Fig. 5b).

\section{Tropical ash spatial distribution pattern}

The analysis of the overall spatial distribution pattern showed that the individuals of tropical ash follow an aggregated or contiguous pattern, varying significantly from a random pattern. This was also true when the analyses were done for each distance class and cover types, always showing an aggregated pattern above the expected value for a random pattern (Fig. 6).

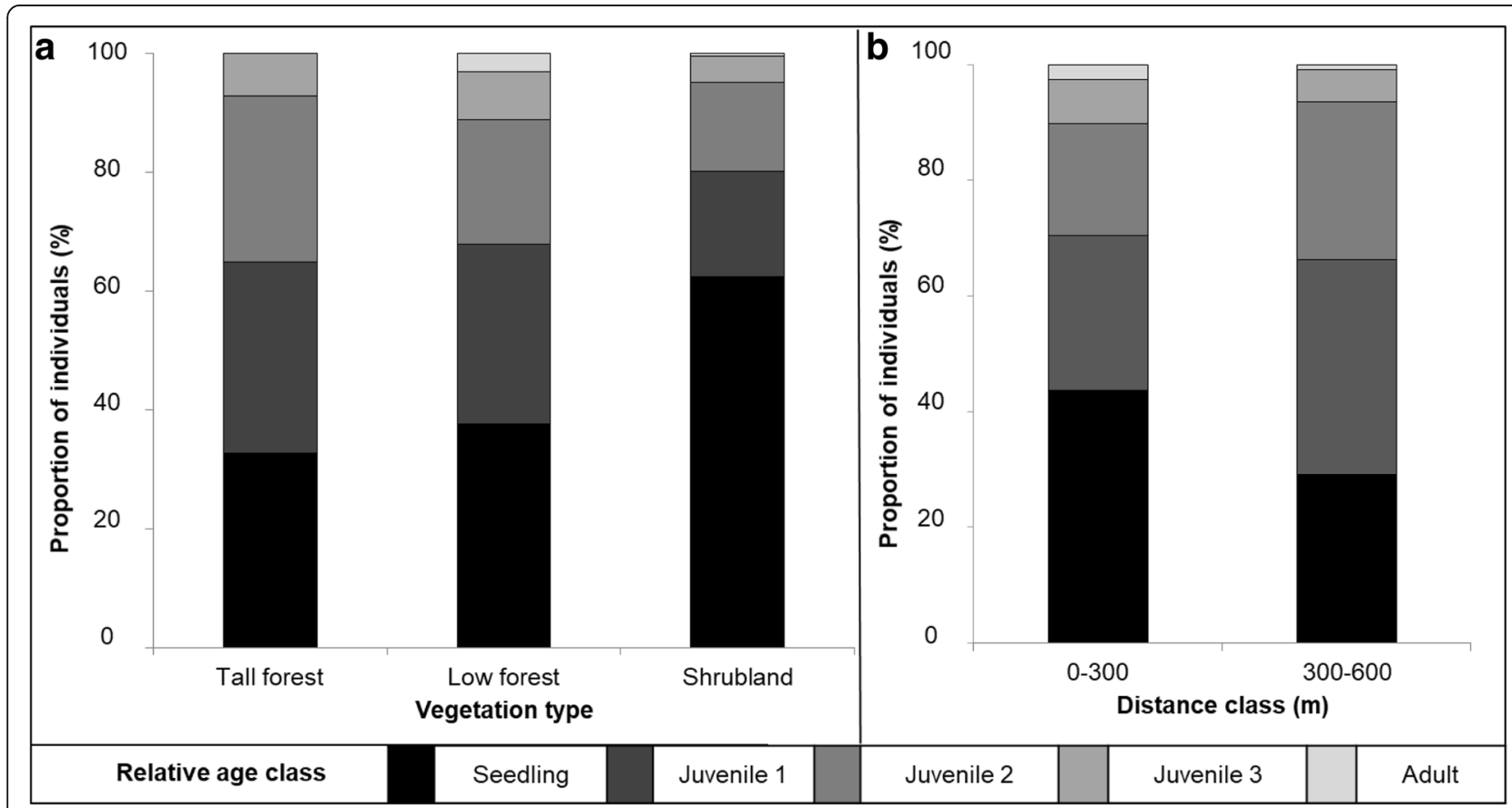

Fig. 4 Proportion of the relative age classes in each vegetation type and distance class. a Proportion of relative age classes in each vegetation type. $\mathbf{b}$ Proportion of relative age classes in each distance class 


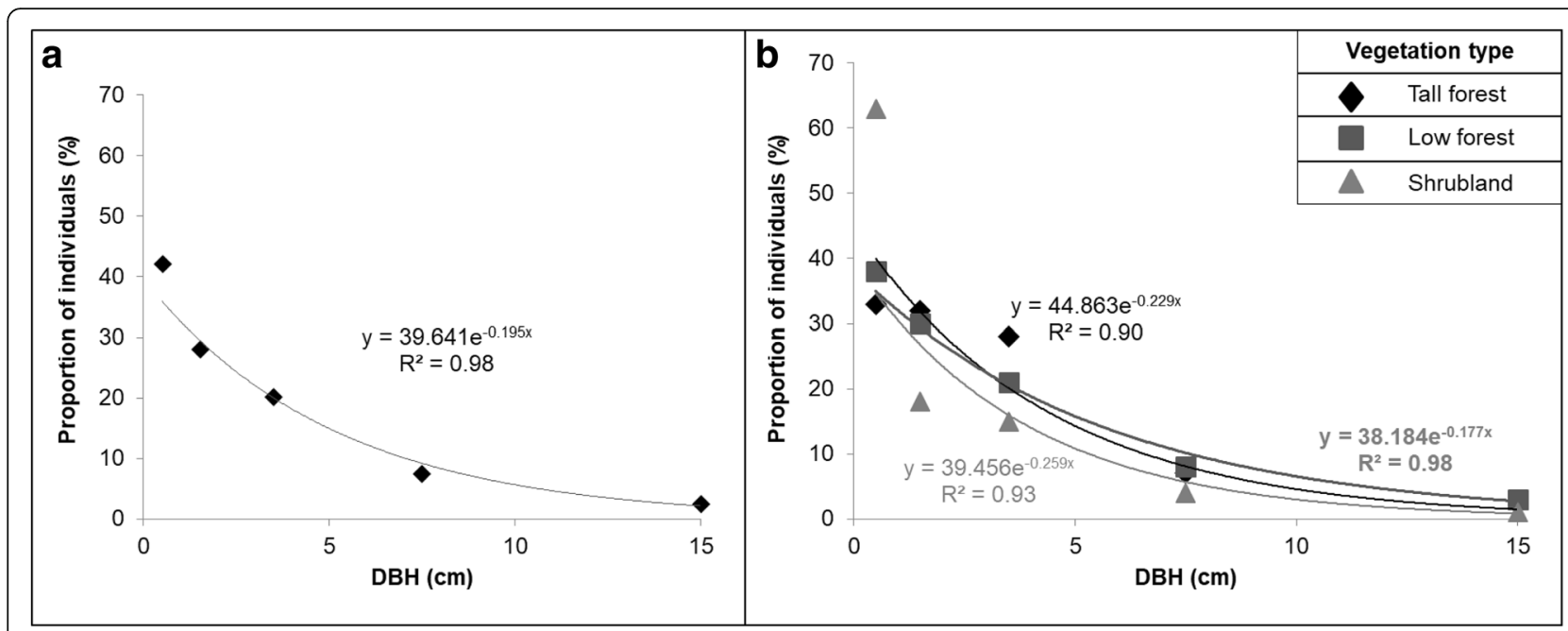

Fig. 5 Survival curve. a Survival for total population of tropical ash. b Population survival by vegetation types

\section{Relations with biophysical variables}

\section{Cover type and distance to propagule source}

A comparison of the distribution of diameter classes in each cover type showed significant differences in their frequencies between shrublands and the tall and low forests (Table 2). The same was observed for the frequencies between the distance classes $0-300 \mathrm{~m}$ and 300$600 \mathrm{~m}$ (Table 2). Furthermore, the probability ( $p$ value) for the frequency comparison of distances classes within each cover type was also significant, except within the tall forest cover. This indicates that each subpopulation appears to have a different diameter structure in each cover type at different distances from the seed sources.

The factorial ANOVA analysis identifies the existence of a statistically significant interaction between distance and cover type for the distribution pattern of adult ash plants (five largest individuals) (Table 3).

A comparison of the medians of the five largest individuals within each cover type-distance class showed that low forest had the greatest significant difference in the 0-300 distance class. However, the analysis also indicated that further away, in the 300-600 distance class,
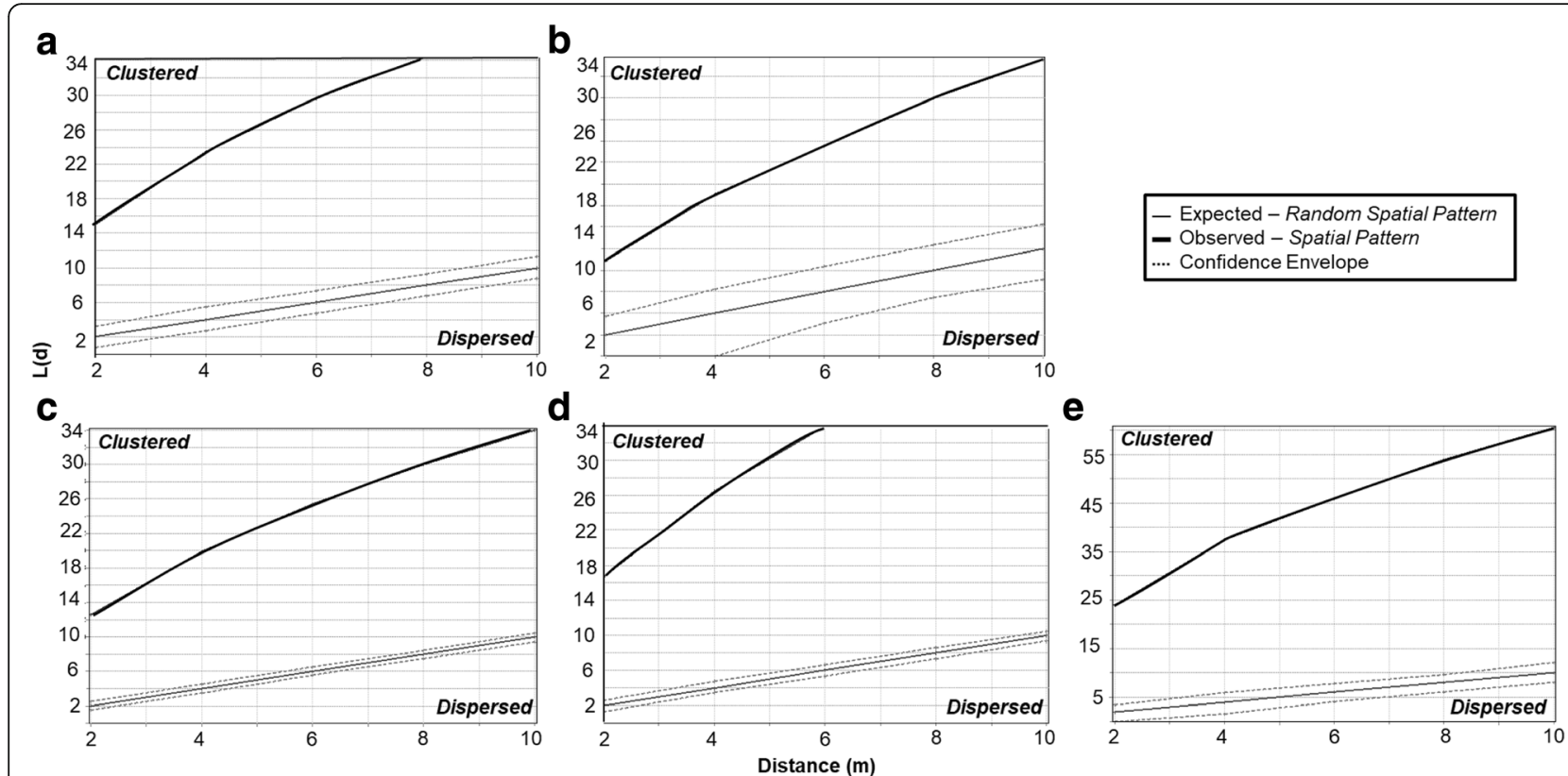

Fig. 6 Spatial distribution pattern of tropical ash for each distance class and vegetation type. a Distance class 300 m. b Distance class $600 \mathrm{~m}$. c Tall forest. d Low forest. e Shrubland 
Table 2 Frequency comparison of vegetation types and distance classes

\begin{tabular}{lll}
\hline Variable & Relation & $p$ value \\
\hline Vegetation type & Tall forest/low forest & 0.08 \\
& Tall forest/shrubland & $9.3 \mathrm{E}-08$ \\
& Low forest/shrubland & $7.2 \mathrm{E}-17$ \\
Distance classes $(\mathrm{m})$ & 0-300/300-600 & $3.3 \mathrm{E}-05$
\end{tabular}

Result of a chi-squared frequency comparison test $\left(x^{2}\right)$ with the diameter categories between vegetation types and distance classes

the three cover types showed no difference in the number of individuals (Table 4). When the analysis was performed for the 10 and 15 largest individuals, the low forest showed the greatest difference in both the $0-300$ and 300-600 distance classes. In terms of distance classes, the first distance range $(0-300 \mathrm{~m})$ presented the greatest variation between cover types (Table 5).

\section{Understory and canopy cover}

For both understory and canopy cover, the intermediate values (class 3) showed overall a higher proportion of ash individuals in the three cover types (Fig. 7). For the understory cover, the lowest proportions were found in the lowest cover class, but in the canopy cover, the two extreme values (class 1 and 5) showed the lowest proportions of individuals. Differences in patterns between cover types was significant $(p<0.05)$, for all except between tall and low forest.

\section{Discussion}

The ecosystems and the invasion problem studied in here are representative of a large area along the interior mountain ranges of the Cundinamarca-Boyacá highplain plateau, where the tropical ash has been extensively planted along fences and gardens. Our study shows strong evidence of an active invasion process of tropical ash into the remnant native forests and shrublands of the hills and mountain ranges of the Bogotá Highplain and highlights a broad spread of propagules into forests over considerable distances from forest borders. In this process, the type of vegetation, distance to propagule source, understory, and canopy cover appear to play important roles and affect the demographic structure of the invading population. Our approach could be easily replicable, and other regions could construct a better understanding of the problem.

\section{Population structure and distribution pattern of tropical ash individuals}

The species abundance and demographic structure within the studied area reflect the conditions of the invasiveness of the species, as well as the invasibility of the ecosystem. Even under harsh conditions of shallow soils, steep slopes, and exposed rocks observed in the shrubland vegetation, the ash individuals are able to establish although they rarely reach beyond a juvenile stage. Furthermore, these results confirm that the spatial distribution pattern of tropical ash described in the study area is closely linked to the establishment ability in disturbed areas (Weber 2003), rather than the soil conditions that stimulate the invasion process (Harrington and Ewell 1997; Villanueva et al. 2015).

This study showed that the reproductive strategy of the species conforms to a "type $r$ " behavior, in agreement with previous studies (Arévalo 2009; García and Murcia 2005). The negative exponential curve of the size classes is relevant because tropical ash studies so far only mention the rapid growth rate of the species (Durán and Kattan 2005; Ares and Fownes 2001). According to Rollet (1980) and Hubbell and Foster (1987), an inverted $J$ structure is associated with shade-tolerant species, as shown in the case of tropical ash demographic pattern or "survival curve".

For a rapidly growing species such as tropical ash (CONABIO 2008), a high abundance of mature reproductive individuals is expected, especially if the species was introduced in the area more than 50 years ago. Surprisingly, this is not yet the case, because less than a quarter of the population has reached the adult stage. Likewise, given that most of the plants were found at intermediate levels of canopy cover and understory cover, the species is assumed to experience some form of interspecific competition, for example, for resources such as light or substrate (Ares and Fownes 2001).

The results of this study confirm that species with wind dispersal mechanisms display an inverse relationship between the distance to seed source and their abundance; it means the abundance decreases while the distance to seed source increases (Harper 1977; Edward et al. 2009; Catford et al. 2011). Besides, the aggregated spatial pattern observed for the species could be explained by the high number of individuals in the low-diameter category, as suggested by Soto et al. (2010). However, an

Table 3 Factorial ANOVA for the five largest individuals within each coverage-distance class

\begin{tabular}{llllll}
\hline & Sum of squares & Degrees of freedom & Mean squares & $F$ & $p$ value \\
\hline Vegetation type & 573.4 & 2 & 286.7 & 56.89 & $8 \mathrm{E}-10$ \\
Distance to propagule source & 213.3 & 1 & 213.3 & 42.34 & $1 \mathrm{E}-06$ \\
Interaction & 443.6 & 2 & 221.8 & 44.01 & $9 \mathrm{E}-09$ \\
\hline
\end{tabular}

The group has five individuals with the highest diameters at breast height 
Table 4 Probability ( $p$ value) of the multiple median comparison tests, for the five largest individuals within each cover type-distance class

\begin{tabular}{lcclll}
\hline & Low forest 300-600 & Shrubland 300-600 & Tall forest 0-300 & Low forest 0-300 & Shrubland 0-300 \\
\hline Tall forest 300-600 & 0.67 & 0.03 & 0.01 & 0.01 & 0.02 \\
Low forest 300-600 & & 0.09 & 0.03 & 0.01 & 0.52 \\
Shrubland 300-600 & & 0.11 & 0.01 & 0.01 \\
Tall forest 0-300 & & & 0.01 & 0.01 \\
Low forest 0-300 & & & 0.01 \\
\hline
\end{tabular}

The group has five individuals with the highest diameters at breast height

aggregated spatial pattern is also expected to be determined by the local environmental conditions (Crawley 2002). Thus, the spatial pattern could be attributed to a combined effect of the distance to propagule source, the type of vegetation cover, the understory cover, and the canopy cover or other factors not addressed in our study, which need to be analyzed in further research.

\section{Relations with biophysical variables}

A number of studies have analyzed the invasion process including the distance to propagule sources (Rouget and Richardson 2003; Sebert-Cuvillier et al. 2008), vegetation cover types (Arévalo 2009; Kuhman et al. 2010), understory cover and canopy cover (Alston and Richardson 2006; Edward et al. 2009). These studies have shown an interaction between the distance to propagule source and the type of vegetation cover, as we observed with the tropical ash abundance, revealing the role of understory and canopy cover in the establishment and development stage of the species. This supports the claim that invasibility and invasiveness interact in such a way (Colautti et al. 2006) that no individual mechanism can by its own fully explain the invasions of plant species (Lamarque et al. 2011).

Contrary to what Tunison (1995) and Ares and Fownes (2001) reported, we found that the dispersion and establishment of tropical ash seeds reach long distances, with individuals being found at more than $500 \mathrm{~m}$ from the seed source. Although wind direction and speed variables were not considered in our study, in this case, the remnant forest that is located in the western flank of Majuy Mountain is influenced by the wind that blows in the northeast direction most of the year (IDEAM, 2014), highlighting that these factors need to be considered to explain the invasion process.

With regard to the types of vegetation cover, the shrubland showed the greatest differences in diametric category frequencies, explained by a larger seedling participation. This result does not support the findings of Arévalo (2009), who indicated that the low forest appears to be the most suitable for the establishment of seeds, although this suitability was related to the lower mortality rate being observed in the low forest. In the case of the tall forest which shows the lower densities, the following aspects can explain the limitations for invasion: (a) presence of more vegetation layers that may prevent the seeds reaching the soil, (b) dense ground layer with a high presence of Chusquea sp. that decreases the probability of establishment, and (c) larger distance from the seedling source. On the other hand, in the case of shrublands, the limitations for invasion could be explained by the following limiting conditions: (a) shallow ground, exposed rock, and steep slopes; (b) positioning on top of the hills, which decreases the probability of seed arrival; and (c) exceedingly dense ground layer that prevents the establishment of specimens.

This study supports the findings of other authors (Arévalo 2009; Edward et al. 2009; Alston and Richardson 2006; Catford et al. 2011), in that the distance to propagule source is the most important variable for explaining the density or abundance of the invasive species. Mathematical modeling has shown that this factor is an important predictor of invasion compared to other factors, such as altitude, geology, or precipitation (Rouget and Richardson 2003).

Table 5 Probability ( $p$ value) of the multiple median comparison tests, for the 10 and 15 largest individuals within each cover type-distance class

\begin{tabular}{llllll}
\hline & Low forest 300-600 & Shrubland 300-600 & Tall forest 0-300 & Low forest 0-300 & Shrubland 0-300 \\
\hline Tall forest 300-600 & 0.01 & $1.5 \mathrm{E}-04$ & $1.3 \mathrm{E}-05$ & $3.3 \mathrm{E}-06$ & $2.6 \mathrm{E}-03$ \\
Low forest 300-600 & & 0.02 & $8.8 \mathrm{E}-04$ & $3.3 \mathrm{E}-06$ & $2.6 \mathrm{E}-03$ \\
Shrubland 300-600 & & 0.11 & $3.3 \mathrm{E}-06$ & $1.5 \mathrm{E}-05$ \\
Tall forest 0-300 & & & $3.3 \mathrm{E}-06$ & $3.3 \mathrm{E}-06$ \\
Low forest 0-300 & & & $3.3 \mathrm{E}-06$ \\
\hline
\end{tabular}

The group has 10 and 15 individuals with the highest diameters at breast height. The result for both groups was the same, and only one table is shown 

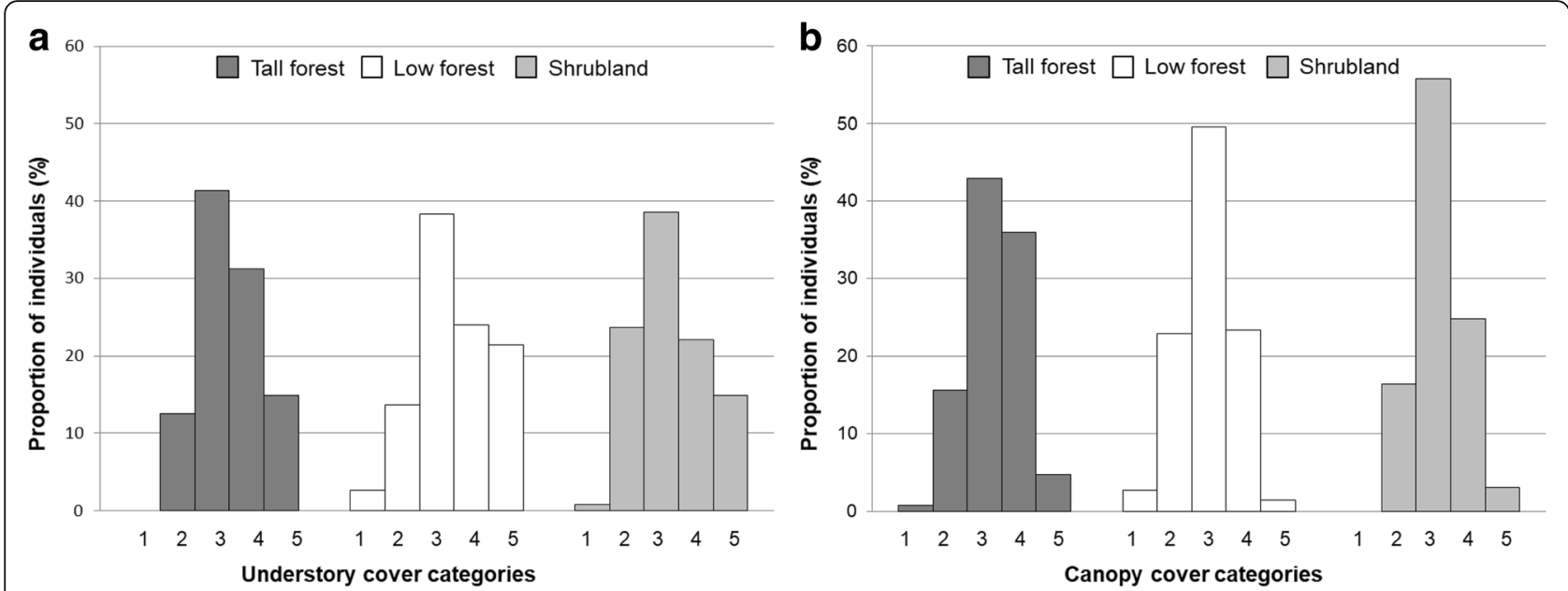

Fig. 7 Proportion of individuals for understory cover and canopy cover categories. a Proportion of individuals in each understory cover category (1 to 5, sparse to dense), by vegetation types. b Proportion of individuals in each canopy cover category (1 to 5, clear to dense), by vegetation types

Future studies should also include wind data and models in order to model and predict potential invasion sites and construct invasion risk maps.

In our study, we did not consider the "edge effects" in the invasion process (Brothers and Springarn 1992; Murcia 1995; Parendes and Jones 2000), which could help explain why the low forest, which shares the larger proportion of edges towards pastures/crops, had the largest quantity of individuals. According to Parendes and Jones (2000), the edges can provide suitable habitats for the propagation of the species and can also contain supplies of seedlings that participate in future invasions.

To complement the results of this study, future studies should address the possible interactions with local flora and fauna, which may influence in a positive or negative way the invasion process of tropical ash, as shown by García and Murcia (2005). Similarly, a closer look at the disturbances from climatic extremes and habitat modifications resulting from the invasion process would provide relevant information regarding the dynamics and impact of the species on the invaded ecosystems (Cuddington and Hastings 2004).

\section{Conclusions}

Our results suggest an active invasion process by the exotic tree tropical ash, into the highly valued remnants of the sub-humid forests in the Andean highlands, pointing to the need for urgent plan interventions on two aspects: the use of the species and the management of the invasion process in the native forests.

In particular, the demographic structure of the species within the native vegetation indicates the characteristics of an expanding population process with a decreasing average age away from propagule sources and with mature reproductive individuals within the native vegetation. This explains that the distance to propagule source variable was a strong predictor of density and size of individuals.

At the same time, the invasion pattern in terms of densities and size distributions showed differences between the three vegetation types, in particular between forests and shrublands, indicating the need to include vegetation maps in this type of research. Differences in terms of understory and canopy cover were not critical for the establishment of propagules.

We observed a strong interaction between the distance to propagule sources and the vegetation types, which is important to take into account when planning control actions and management of tropical ash in the future.

\section{Additional file}

Additional file 1: Dataset of tropical ash individuals. (XLSX $86 \mathrm{~kb}$ )

\section{Abbreviations}

asl: Above sea level; DBH: Diameter at breast height

\section{Acknowledgements}

We thank the property owners for their support and financing field assistants Marcelino and Felipe, who were very helpful during fieldwork. Paulo Arévalo and Paula Amaya provided support in data analysis and helpful discussions.

\section{Availability of data and materials}

The dataset supporting the conclusions of this article is included within the article and its additional files (see Additional file 1).

\section{Authors' contributions}

KAS-R and AE conceived and designed the experiments and analyzed the data. KAS-R performed the experiments and prepared the figures and/or tables. KAS-R, AR, and AE drafted the work or revised it critically for important content. All authors read and approved the final manuscript. 


\section{Ethics approval and consent to participate}

Not applicable

\section{Competing interests}

The authors declare that they have no competing interests.

\section{Publisher's Note}

Springer Nature remains neutral with regard to jurisdictional claims in published maps and institutional affiliations.

\section{Received: 26 February 2018 Accepted: 24 April 2018}

\section{Published online: 21 May 2018}

\section{References}

Aizen MA, Morales CL, Morales JM (2008) Invasive mutualists erode native pollination webs. PLoS Biol 6(2):396-406

Alpert P, Bone E, Holzapfel C (2000) Invasiveness, invasibility and the role of environmental stress in the spread of non-native plant. Perspectives in Plant Ecology, Evolution and Systematics 3(1):52-66

Alston KP, Richardson DM (2006) The roles of habitat features, disturbance, and distance from putative source populations in structuring alien plant invasions at the urban/wildland interface on the Cape Peninsula, South Africa. Biol Conserv 132(2):183-198

ArcGIS Resources (2014) Análisis cluster espacial de distancia múltiple (Función K de Ripley). Available at https://doc.arcgis.com/en/. Accessed 10 June 2015

Ares A, Fownes JH (2001) Productivity, resource use, and competitive interactions of Fraxinus uhdei in Hawaii uplands. Can J For Res 31(1):132-142

Arévalo P (2009) Topical ash (Fraxinus uhdei) invading Andean forests in central Colombia: a modeling approach using statistical methods. Thesis, Pontificia Universidad Javeriana, Bogotá

Baptiste MP, Castaño N, Cárdenas D, Gutiérrez F, Gil D, Lasso CA (2010) Análisis de riesgo y propuesta de categorización de especies introducidas para Colombia. Instituto de Investigación de Recursos Biológicos Alexander von Humboldt, Bogotá D.C

Berrio J, Dávila A, Giraldo V, Hernández RJ, Camacho E, Lozano D, Acosta I (2006) La reforestación en Colombia. Visión de futuro. FEDEMADERAS, Bogotá D.C

Booth BD, Murphy SD, Swanton CJ (2004) Invasive ecology of weeds in agricultural system. In: Inderjit (ed). Weed biology and management. Springer, Dordrecht

Brothers T, Springarn A (1992) Forest fragmentation and alien plant invasion of Central Indiana old-growth forests. Conserv Biol 6(1):91-100

Canham CD, Murphy $L$ (2017) The demography of tree species response to climate: sapling and canopy tree survival. Ecosphere 8(2):e01701

Catford JA, Vesk PA, White MD, Wintle BA (2011) Hotspots of plant invasion predicted by propagule pressure and ecosystem characteristics. Diversity and Distribution 17(6):1099-1110

Colautti RI, Grigorovich IA, Maclsaac HJ (2006) Propagule pressure: a null model for biological invasions. Biol Invasions 8(5):1023-1037

Colombian Institute of Hydrology Meteorology and Environmental Studies-IDEAM (2014) Rosa de vientos Santafé de Bogotá. Available at http://institucional.ideam.gov.co. Accessed 14 Jan 2015

Crawley ML (2002) Plant ecology. Blackwell Publishing Ltd., Oxford

Crichigno S, Cordero P, Blasetti G, Cussac V (2016) Dispersion of the invasive common carp Cyprinus carpio in southern South America: changes and expectations, westward and southward. J Fish Biol 89:403-416

Cuddington K, Hastings A (2004) Invasive engineers. Ecol Model 178:335-347

Dickens SJM, Allen EB (2013) Exotic plant invasion alters chaparral ecosystem resistance and resilience pre- and post-wildfire. Biol Invasions 16(5):1119-1130

DigitalGlobe (2009) Bogota high plain image. Worldview-2 [Satellite image]

Dixon PM (2002) Ripley's function. In: AH El-S, Piegorsch WW (eds) Encyclopedia of environmetrics. Jonh Wiley, United Kingdom

Dong LB, Zang B, Yuan Y, Sun YX (2014) Forest landscapes' spatial point patterns and associations based on Ripley $L$ and O-ring functions (in Chinese). J applied ecology 25(12):3429-3436

Durán SM, Kattan GH (2005) A test of the utility of exotic tree plantations for understory birds and food resources in the Colombian Andes. Biotropica 37(1):129-135

EcoNat Ltda, Fundación Cerros de Bogotá (2013) Plan de manejo ambiental (PMA) Universidad de los Andes Hacienda el Noviciado https://www. cerrosdebogota.org/cerros/landing/. (Accessed 14 Jan 2015)
Edward E, Munishi PKT, Hulme PE (2009) Relative roles of disturbance and propagule pressure on the invasion of humid tropical forest by Cordia alliodora (Boraginaceae) in Tanzania. Biotropica 41(2):171-178

ESRI (2010) ArcGIS desktop: release 10. Environmental Systems Research Institute, Redlands

Etter A, McAlpine C, Possingham H (2008) A historical analysis of the spatial and temporal drivers of landscape change in Colombia since 1500. Ann Assoc Am Geogr 98:1-27

Fine PV (2002) The invasibility of tropical forests by exotic plants. J Trop Ecol 18(5):687-705

Fonton N, Atindogbe G, Honkonnou N, Dohou R (2011) Plot size for modeling the spatial structure of Sudanian woodland trees. Ann For Sci 68(8):1315-1321

Food and Agriculture Organization of the United States_FAO (2014) State of the world's forests 2014. FAO, Rome. Available at http://www.fao.org. Accessed 14 Jan 2015

Galbraith D, Malhi Y, Aragão L, Baker T (2014) The ecosystem dynamics of Amazonian and Andean forests. Plant Ecology Diversity 7(1-2):1-6

García CA, Murcia C (2005) Comparative habitat susceptibility to invasion by Chinese ash (Fraxinus chinensis: Oleaceae) in a tropical Andean landscape. Biol Invasions 7(1):405-415

Gareca EE, Martinez YY, Bustamante RO, Aguirre LF, Siles MM (2007) Regeneration patterns of Polylepis subtusalbida growing with the exotic trees Pinus radiata and Eucalyptus globulus at Parque Nacional Tunari, Bolivia. Plant Ecol 193:253-263

Grizonnet M, Inglada J (2010) Monteverdi-remote sensing software from educational to operational context. In: 30th EARSeL Symposium: Remote Sensing for Science. Education and Culture, Paris

Gutiérrez F (2006) Estado de conocimiento de especies invasoras. Propuesta de lineamientos para el control de los impactos. Instituto de Investigación de Recursos Biológicos Alexander von Humboldt, Bogotá D.C

Haase P (1995) Spatial pattern analysis in ecology based on Ripley's K-function: introduction and methods of edge correction. J Veg Sci 6(4):575-582

Hammer $\varnothing$, Harper DAT, Ryan PD (2001) PAST: paleontological statistics software package for education and data analysis. Palaeontol Electron 4(1):1-9

Harper JL (1977) Population biology of plants. London Academic Press, United Kingdom

Harrington RA, Ewell JJ (1997) Invasibility of tree plantations by native and non-indigenous plant species in Hawaii. For Ecol Manag 99(1/2):153-162

Hernández-Camacho J, Ortiz-Quijano R, Walshburger T, Hurtado-Guerra A (1992) Estado de la biodiversidad en Colombia. In: Halffter G (ed) La diversidad biológica de Iberoamérica. I. INECOL, México

Higuchi P, Silva AC, Lauzada JNC, Machado ELM (2010) Spatial patterns of a tropical tree species growing under an eucalyptus plantation in South-East Brazil. Braz J Biol 70(2):271-277

Hubbell SP, Foster RB (1987) La estructura espacial en gran escala de un bosque neotropical. Revista de Biología Tropical 35(1):7-22

Hughes CE (1994) Risk of species introductions in tropical forestry. Commonwealth Forestry Rev 73(4):243-252

Inderjit (2005) Plant invasions: habitat invasibility and dominance of invasive plant species. Plant Soil 1(2):1-5

Infante J (1958) El tropical ash. Revista Nacional de Agricultura 52(634):30-33

Kashian DM (2016) Sprouting and seed production may promote persistence of green ash in the presence of the emerald ash borer. Ecosphere 7(4): e01332

Kuhman T, Pearson S, Turner M (2010) Effects of land-use history and the contemporary landscape on non-native plant invasion at local and regional scales in the forest-dominated southern Appalachians. Landsc Ecol 25(9):1433-1445

Lamarque L, Delzon S, Lortie C (2011) Tree invasions: a comparative test of the dominant hypotheses and functional traits. Biol Invasions 13(9):1969-1989

Lauenroth WK, Adler PB (2008) Demography of perennial grassland plants: survival, life expectancy and life span. J Ecol 96(5):1023-1032

Martyniuk NA, Morales CL, Aizen M (2015) Invasive conifers reduce seed set of a native Andean cedar through heterospecific pollination competition. Biol Invasions 17:1055-1067

Millenium Ecosystem Assessment-MEA (2005) Ecosystems and human well-being. Biodiversity Synthesis. World Resources Institute, Washington D.C

Montañez LE, Cereh A (2013) Propuesta de un corredor ecológico entre la Reserva Forestal Regional Productora del Norte de Bogotá y el cerro de Majuy (Cota). Corporación Autónoma Regional de Cundinamarca-CAR, Bogotá D.C 
Morales CL, Aizen MA (2002) Does invasion of exotic plants promote invasion of exotic flower visitors? A case study from the temperate forests of the southern Andes. Biol Invasions 4:87-100

Mullah CJA, Klanderud K, Totland $\varnothing$, Odee D (2014) Community invasibility and invasion by non-native Fraxinus pennsylvanica trees in a degraded tropical forest. Biol Invasions 16(12):2747-2755

Murcia C (1995) Edge effects in fragmented forests: implications for conservation. Trends in Ecology Evolution 10:58-62

Muvengwi J, Mbiba M, Chikumbindi J, Ndagurwa H, Mureva A (2018) Population structure and spatial point-pattern analysis of a mono stand of Acacia polyacantha along a catena in a savanna ecosystem. For Ecol Manag 409(1):499-508

Myers N, Mittermeier RA, Mittermeier CG, da Fonseca GAB, Kent J (2000) Biodiversity hotspots for conservation priorities. Nature 403:853-858

National Commission for Knowledge and Use of Biodiversity —CONABIO (2008) Fraxinus uhdei. Available at http://www.conabio.gob.mx. Accessed 15 Oct 2014

Orme CDL, Davies RG, Burgess M, Eigenbrod F, Pickup N, Olson VA, Webster AJ, Ding TS, Rasmussen PC, Ridgely RS, Stattersfield AJ, Bennett PM, Blackburn TM, Gaston KJ, Owens IPF (2005) Global hotspots of species richness are not congruent with endemism or threat. Nature 436:1016-1019

OTB Team (2014) The Orfeo ToolBox Cookbook, a guide for non-developers Updated for OTB-4.2. Available at http://www.orfeo-toolbox.org/CookBook/. Accessed 20 Sept 2014

Palik BJ, Ostry ME, Vennette RC, Abdela E (2012) Tree regeneration in black ash (Fraxinus nigra) stands exhibiting crown dieback in Minnesota. For Ecol Manag 269:26-30

Parendes LA, Jones JA (2000) Role of light availability and dispersal in exotic plant invasion along roads and streams in the $\mathrm{H}$. J. Andrews Experimental Forest, Oregon. Conserv Biol 14(1):64-75

Pyle LL (1995) Effects of disturbance on herbaceous exotic plan species on the floodplain of the Potomac River. Am Midl Nat 134(2):244-253

Richardson DM, Cowling RM (1994) The ecology of invasive alien pines (Pinus spp.) in the Jonkershoek Valley, Stellenbosch, South Africa. Bontebok 9:1-10

Rodríguez W (1997) Regeneración natural y sucesión vegetal temprana en un matorral altoandino afectado pro fuego (Cota, Cundinamarca), Thesis. Pontificia Universidad Javeriana, Bogotá

Rollet B (1980) El bosque tropical y la biosfera. In: Unesco, Programa de las Naciones Unidas para el Medio Ambiente -PNUMA, Food and Agriculture Organization of the United States -FAO (ed) Ecosistemas de bosques tropicales: informe sobre el estado de conocimientos. UNESCO-CIFCA, París

Rothstein DE, Vitousek PM, Simmons BL (2004) An exotic tree alters decomposition and nutrient cycling in a Hawaiian montane forest. Ecosystems 7(8):805-814

Rouget M, Richardson DM (2003) Inferring process from pattern in plant invasions: a semimechanistic model incorporating propagule pressure and environmental factors. Am Nat 162(6):713-724

Sebert-Cuvillier E, Simon-Goyheneche V, Paccaut F, Chabrerie O, Goubet O, Decocq G (2008) Spatial spread of an alien tree species in a heterogeneous forest landscape: a spatially realistic simulation model. Landsc Ecol 23(7):787-801

Smith CW (1985) Impacts of alien plants on Hawaii's native biota. In: Stone CP, Scott JM (eds) Hawaii terrestrial ecosystems; preservation and management Cooperative Park Studies Unit. University of Hawaii, Honolulu

Soto D, Salas C, Donoso P, Uteau D (2010) Heterogeneidad estructural y espacial de un bosque mixto dominado por Nothofagus dombeyi después de un disturbio parcial. Rev Chil Hist Nat 83:335-347

Trujillo E (2012) Otro enfoque para entender la "Reforestación Comercial". Available at http://www.revista-mm.com/. Accessed 10 Oct 2014

Tunison T (1995) Fraxinus uhdei. The Nature Conservancy Element Stewardship Abstract, Honolulu

US Forest Service, Pacific Island Ecosystem at Risk_-PIER (2008) Fraxinus uhdei risk assessment. Available at http://www.hear.org/pier/wra/pacific/fraxinus uhdei_htmlwra.htm. Accessed 4 Sept 2014

Vallejo MI, Galeano G (2009) Short-term temporal changes in the spatial patterns of nine species of common plants in an Andean cloud forest in southwestern Colombia. Caldasia 31(1):77-98
Villanueva J, Pérez E, Beramendi L, Cerano J (2015) Crecimiento radial anual del fresno (Fraxinus udhei (Wenz.) Lingelsh.) en dos parques de la Comarca Lagunera. Revista Mexicana de Ciencias Forestales 6(31):40-57

Weber E (2003) Invasive plant species of the world: a reference guide to environmental weeds. CAB International, Wallingford

Yalcin S, Leroux SJ (2017) Diversity and suitability of existing methods and metrics for quantifying species range shifts. Glob Ecol Biogeogr 26:609-624

\section{Submit your manuscript to a SpringerOpen ${ }^{\circ}$ journal and benefit from:}

- Convenient online submission

- Rigorous peer review

- Open access: articles freely available online

- High visibility within the field

Retaining the copyright to your article

Submit your next manuscript at $>$ springeropen.com 